\title{
Omega-3 Polyunsaturated Fatty Acids Attenuate Radiation-induced Oxidative Stress and Organ Dysfunctions in Rats
}

\author{
N. Abdel Aziz and S. F. Yacoub
}

Radiation Biology Dept., National Centre for Radiation Research and Technology (NCRRT), P. O. Box; 29 Nasr City, Egypt.

\footnotetext{
7 HE AIM of the present study was to determine the possible protective effect of omega-3 polyunsaturated fatty acids (omega-3 PUFA) against radiation-induced oxidative stress associated with organ dysfunctions. Omega-3 PUFA was administered by oral gavages to male albino rats at a dose of 0.4 $\mathrm{g} / \mathrm{kg}$ body wt daily for 4 weeks before whole body $\gamma$-irradiation with $4 \mathrm{~Gy}$. Significant increase of serum lipid peroxidation end product as malondialdehyde (MDA) along with the reduction in blood glutathione (GSH) content, superoxide dismutase (SOD) and glutathione peroxidase (GPX) enzyme activities were recorded on $3^{\text {rd }}$ and $8^{\text {th }}$ days post-irradiation.

Oxidative stress was associated with a significant increase in lactate dehydrogenase (LDH) and creatine phosphokinase (CPK) enzyme activities, markers of heart damage, significant increases in uric acid, urea and creatinine levels, markers of kidney damage, significant increases of alkaline phosphatase (ALP) and transaminases (ALT \& AST) activities, markers of liver damage. Moreover significant increases in total cholesterol and triglycerides levels were recorded. Omega-3 PUFA administration pre-irradiation significantly attenuated the radiation-induced oxidative stress and organ dysfunctions tested in this study. It could be concluded that oral supplementation of omega-3 PUFA before irradiation may afford protection against radiation-induced oxidative stress and might preserve the integrity of tissue functions of the organs under investigations.

Keywords: Omega-3, $\gamma$-rays, rats, liver, heart, kidney.
}

Exposure to ionizing radiation initiates a cascade of events including oxidative damage that leads to alteration of tissue physiological function (Zhao et al., 2007). Lipid peroxidation is considered to be a critical event of ionizing radiation effect (Agrawal and Kale, 2001). 
Most of the toxic effects of ionizing radiation are due to generation of reactive oxygen species (ROS) by radiolysis of water which triggers formation of several reactive intermediates (Adaramoye et al., 2011). Therefore, to overcome this oxidant stress, the body is equipped with defence system, including enzymatic and non-enzymatic radical scavengers that can either directly detoxify ROS or indirectly regulate their levels (Sandeep and Nair, 2012). Hence, an over production of ROS leads to uncontrolled chain reactions and lipid peroxidation, resulting in various pathological conditions that may include liver injury (Kotzampassi et al., 2009), testicular tissues injury (Adaramoye et al., 2012), lung and kidney damage (Sener et al., 2006).

Omega-3 PUFAs are essential long chain polyunsaturated fatty acids of plant and marine origin. Flax seed is generally a rich source of the omega-3 PUFA alpha linolenic acid. However, docosahexaenoic acid (DHA) eicosapentaenoic acid (EPA) are the predominant omega-3 PUFAs in fish oil.

Omega-3 PUFAs play an important role in the protection of cells against ROS by increasing the activity of antioxidant enzymes (Bhattacharya et al., 2007). Moreover, their beneficial effects have been shown in the prevention and management of heart failure (Rupp et al., 2012), cardiovascular diseases (Lavie et al., 2009), liver diseases (Kotzampassi1 et al., 2009), obesity prevention (Tai and Ding, 2010) and kidney disease (Miller et al., 2009). Therefore, the present study was undertaken to investigate the possible radio protective effect of omega-3 PUFAs against oxidative damage associated with some organ dysfunctions namely liver, kidney and heart.

\section{Material and methods}

Male albino rats $7 \pm 1$ weeks weighing 120-150 g were obtained from the Egyptian Holding Company for Biological Products and Vaccine, Helwan, Cairo. Animals were kept under good ventilation conditions and had free access to water and standard pellet concentrated diet.

\section{Radiation facility}

Whole body gamma irradiation was performed with a ventilated Canadian

${ }^{137} \mathrm{Cs}$ gamma cell-40 at the NCRRT, Cairo, Egypt at a dose rate of $0.48 \mathrm{~Gy} / \mathrm{min}$. Rats were exposed to $4 \mathrm{~Gy}$ delivered as a single shot dose.

Egypt. J. Rad. Sci. Applic., Vol. 26, No. 1-2 (2013) 


\section{Omega-3 PUFAs}

Omega-3 PUFAs oil was purchased from SEDICO Pharmaceutical Co., Egypt. It was available in the form of capsules containing $1.0 \mathrm{~g}$ omega-3 fish oil EPA and DHA. Each rat was orally administered $0.4 \mathrm{~g} / \mathrm{kg}$ body wt/ day (Erdogan et al., 2004) via oral gavages for 4 weeks. Higher doses were found to cause increased lipid peroxidation (Ibrahim et al., 2011).

\section{Experimental design}

Animals were divided into 4 equal groups each of 5 rats. Control rats; Omega-3: Rats received omega-3 daily for 4 weeks; Irradiated: Rats were whole body exposed to 4Gy $\gamma$-rays and Omega-3+ irradiation: Rats received omega-3 for 4 weeks before irradiation at $4 \mathrm{~Gy}$. The animals were sacrificed on the $3^{\text {rd }}$ and $8^{\text {th }}$ days post irradiation and/ or Omega-3-treatment.

\section{Biochemical analysis}

Animals were lightly anesthetized with ether and blood was collected by heart puncture. The blood content of GSH was determined as described by Beutler et al. (1963) whereas SOD and GPX enzyme activities were verified according to Misra and Fridovich (1972) and Paglia and Valentine (1967), respectively. Serum was separated by blood centrifugation at $3000 \mathrm{rpm}$ for estimation of lipid peroxidation indicated by formation of MDA using the method described by Yoshioka et al. (1979). LDH and CPK activities were determined according to the method of Henderson and Moss (2001) and Rec (1977), respectively. Uric acid, creatinine and urea contents were determined according to Barham and Trinder (1972), Henry (1974) and Patton and Crouch (1977), respectively. Cholesterol, triglycerides, transaminases; ALT \& AST and ALP were determined according to Richmond (1973), Fossati and Principe (1982), Reitman and Frankel (1957) and Belfield and Goldberg (1971), respectively.

\section{Statistical analysis}

The SPSS/PC computer program was used for statistical analysis of the results. Values were expressed as (mean \pm S.E.). Statistical comparison between groups was done by using one way ANOVA. Differences were considered significant at $P<0.05$. 


\section{Results}

The results obtained revealed that supplementation of omega-3 PUFAs to normal rats induced a significant increase $(P<0.05)$ of GSH content at 3 days. Irradiation provoked a significant increase $(P<0.05)$ in serum MDA associated with a significant decrease $(P<0.05)$ of GSH content and SOD and GPX enzyme activities, 3 and 8 days post irradiation, compared to control values. Omega- 3 supplementation before irradiation significantly lowered MDA level and increased SOD enzyme activity and GSH content, compared to their respective values in irradiated rats (Table 1).

TABLE. Effect of Omega-3 PUFAs on serum MDA level, blood GSH content, SOD and GPX enzyme activities of rats exposed to gamma irradiation (4Gy).

\begin{tabular}{|c|c|c|c|c|c|}
\hline Groups & Days & GSH $(\mathrm{mg} / \mathrm{dl})$ & MDA $(\mu \mathrm{mol} / \mathrm{L})$ & SOD $(\mathrm{U} / \mathrm{ml})$ & GPX $(\mathrm{U} / \mathrm{ml})$ \\
\hline Control & - & $37.80 \pm 2.18^{\text {bc }}$ & $58.86 \pm 2.19^{\text {cd }}$ & $13.73 \pm 0.31^{\mathbf{c}}$ & $5.07 \pm 0.26^{\mathbf{c}}$ \\
\hline \multirow{2}{*}{ Omega-3 } & $3^{\text {rd }}$ & $46.38 \pm 2.90^{\text {acd }}$ & $66.24 \pm 3.49^{\mathbf{c}}$ & $13.53 \pm 0.39^{\mathbf{c}}$ & $4.61 \pm 0.30$ \\
\cline { 2 - 6 } & $8^{\text {th }}$ & $44.90 \pm 3.53^{\text {cd }}$ & $68.20 \pm 4.22^{\mathbf{c}}$ & $13.59 \pm 0.41^{\mathbf{c}}$ & $4.73 \pm 0.35^{\mathbf{c}}$ \\
\hline \multirow{2}{*}{ Irradiation } & $3^{\text {rd }}$ & $28.22 \pm 2.69^{\text {ab }}$ & $95.56 \pm 2.96^{\text {abd }}$ & $8.33 \pm 0.58^{\text {abd }}$ & $3.86 \pm 0.31^{\mathbf{a}}$ \\
\cline { 2 - 6 } & $8^{\text {th }}$ & $24.04 \pm 3.48^{\text {abd }}$ & $92.60 \pm 4.73^{\text {abd }}$ & $7.79 \pm 0.46^{\text {abd }}$ & $3.81 \pm 0.31^{\text {ab }}$ \\
\hline \multirow{2}{*}{$\begin{array}{c}\text { Omega-3+ } \\
\text { Irradiation }\end{array}$} & $3^{\text {rd }}$ & $35.04 \pm 2.38^{\mathbf{b}}$ & $77.22 \pm 3.60^{\text {ac }}$ & $12.35 \pm 0.63^{\mathbf{c}}$ & $4.64 \pm 0.30$ \\
\cline { 2 - 6 } & $8^{\text {th }}$ & $36.18 \pm 2.66^{\text {bc }}$ & $70.22 \pm 5.09^{\mathbf{c}}$ & $12.95 \pm 0.55^{\mathbf{c}}$ & $4.65 \pm 0.32$ \\
\hline
\end{tabular}

Data are represented as means \pm S.E. $(n=5) .{ }^{\text {a. }}$ : Significantly different from control, ${ }^{\text {b : Significantly }}$

different from omega-3, ${ }^{\text {c: }}$ : Significantly different from irradiated, ${ }^{d}$ : Significantly different from omega3+ irradiation.

Irradiation induced significant increases $(P<0.05)$ in serum cholesterol and triglyceride levels, 3 and 8 days post irradiation. Supplementation of omega- 3 before irradiation has no significant effect on cholesterol levels, compared to irradiated values, while ameliorated triglyceride levels on the $3^{\text {rd }}$ and $8^{\text {th }}$ days (Table 2).

TABLE 2. Effect of Omega 3 PUFAs on serum cholesterol and triglyceride levels of rats exposed to gamma irradiation (4Gy).

\begin{tabular}{|c|c|c|c|}
\hline Groups & Days & Cholesterol $(\mathrm{mg} / \mathrm{dl})$ & Triglycerides $(\mathrm{mg} / \mathrm{dl})$ \\
\hline Control & - & $86.20 \pm 3.99^{\text {cd }}$ & $87.20 \pm 3.17^{\mathbf{c}}$ \\
\hline \multirow{2}{*}{ Omega-3 } & $3^{\text {rd }}$ & $81.20 \pm 3.25^{\text {cd }}$ & $79.40 \pm 3.46^{\text {cd }}$ \\
\cline { 2 - 4 } & $8^{\text {th }}$ & $80.40 \pm 3.78^{\text {cd }}$ & $78.60 \pm 3.71^{\text {cd }}$ \\
\hline \multirow{2}{*}{ Irradiation } & $3^{\text {rd }}$ & $107.20 \pm 7.55^{\text {ab }}$ & $98.40 \pm 4.31^{\text {ab }}$ \\
\cline { 2 - 4 } & $8^{\text {th }}$ & $102.40 \pm 6.77^{\text {ab }}$ & $100.40 \pm 4.95^{\text {ab }}$ \\
\hline \multirow{2}{*}{$\begin{array}{c}\text { Omega-3+ } \\
\text { Irradiation }\end{array}$} & $3^{\text {rd }}$ & $104.80 \pm 4.42^{\text {ab }}$ & $92.40 \pm 3.71^{\mathbf{b}}$ \\
\cline { 2 - 4 } & $8^{\text {th }}$ & $100.40 \pm 6.36^{\mathbf{b}}$ & $92.60 \pm 3.94^{\mathbf{b}}$ \\
\hline
\end{tabular}

Legends as Table 1.

Egypt. J. Rad. Sci. Applic., Vol. 26, No. 1-2 (2013) 
Significant increases in serum LDH and AST activities were recorded 8 days post irradiation while CPK, ALT and ALP activities showed an increase, 3 and 8 days post irradiation compared to control values. Administration of omega- 3 before irradiation reduced the increase of enzyme activities compared to irradiated values (Tables $3 \& 4$ ).

TABLE. Effect of Omega 3 PUFA on serum ALT and ALP enzyme activities of rats exposed to gamma irradiation (4Gy).

\begin{tabular}{|c|c|c|c|}
\hline Groups & Days & ALT $(\mathrm{U} / \mathrm{L})$ & ALP $(\mathrm{U} / \mathrm{L})$ \\
\hline Control & - & $19.46 \pm 0.81^{\text {cd }}$ & $20.62 \pm 1.54^{\mathbf{c}}$ \\
\hline \multirow{2}{*}{ Omega-3 } & $3^{\text {rd }}$ & $18.96 \pm 0.97^{\text {cd }}$ & $20.78 \pm 11.93^{\mathbf{c}}$ \\
\cline { 2 - 4 } & $8^{\text {th }}$ & $18.68 \pm 0.80^{\text {cd }}$ & $20.98 \pm 1.98^{\mathbf{c}}$ \\
\hline \multirow{2}{*}{ Irradiation } & $3^{\text {rd }}$ & $26.64 \pm 0.94^{\text {abd }}$ & $29.02 \pm 2.59^{\text {ab }}$ \\
\cline { 2 - 4 } & $8^{\text {th }}$ & $28.00 \pm 0.84^{\text {abd }}$ & $30.22 \pm 3.33^{\text {ab }}$ \\
\hline \multirow{2}{*}{$\begin{array}{c}\text { Omega-3+ } \\
\text { Irradiation }\end{array}$} & $3^{\text {rd }}$ & $22.00 \pm 1.10^{\text {bc }}$ & $26.38 \pm 2.46$ \\
\cline { 2 - 4 } & $8^{\text {th }}$ & $22.60 \pm 1.21^{\text {abc }}$ & $25.36 \pm 2.92$ \\
\hline
\end{tabular}

Legends as Table 1.

TABLE 4. Effect of Omega 3 PUFA on serum LDH, CPK and AST enzyme activities of rats exposed to gamma irradiation (4Gy).

\begin{tabular}{|c|c|c|c|c|}
\hline Groups & Days & LDH $(\mathrm{U} / \mathrm{ml})$ & CPK $(\mathrm{U} / \mathrm{ml})$ & AST $(\mathrm{U} / \mathrm{L})$ \\
\hline Control & - & $66.00 \pm 4.43^{\mathbf{c}}$ & $138.40 \pm 6.44^{\text {cd }}$ & $62.80 \pm 2.63^{\mathbf{c}}$ \\
\hline \multirow{2}{*}{ Omega-3 } & $3^{\text {rd }}$ & $65.20 \pm 4.96$ & $135.20 \pm 5.54^{\text {cd }}$ & $56.40 \pm 2.25$ \\
\cline { 2 - 5 } & $8^{\text {th }}$ & $64.80 \pm 5.38^{\mathbf{c}}$ & $133.80 \pm 5.48^{\text {cd }}$ & $56.40 \pm 2.32^{\mathbf{c}}$ \\
\hline \multirow{2}{*}{ Irradiation } & $3^{\text {rd }}$ & $81.20 \pm 7.11$ & $227.40 \pm 9.18^{\text {abd }}$ & $64.80 \pm 5.12$ \\
\cline { 2 - 5 } & $8^{\text {th }}$ & $83.20 \pm 7.96^{\text {ab }}$ & $233.80 \pm 8.10^{\text {abd }}$ & $74.60 \pm 4.34^{\text {ab }}$ \\
\hline \multirow{2}{*}{$\begin{array}{c}\text { Omega-3+ } \\
\text { Irradiation }\end{array}$} & $3^{\text {rd }}$ & $72.40 \pm 4.08$ & $161.40 \pm 6.82^{\text {abc }}$ & $64.00 \pm 3.49$ \\
\cline { 2 - 5 } & $8^{\text {th }}$ & $72.20 \pm 5.51$ & $158.40 \pm 5.94^{\text {bc }}$ & $65.00 \pm 2.14$ \\
\hline
\end{tabular}

Legends as Table 1.

TABLE 5. Effect of Omega 3 PUFA on serum uric acid, creatinine and urea levels of rats exposed to gamma irradiation (4Gy).

\begin{tabular}{|c|c|c|c|c|}
\hline Groups & Days & Uric acid (mg/ dl ) & Creatinine $(\mathrm{mg} / \mathrm{dl})$ & Urea $(\mathrm{mg} / \mathrm{dl})$ \\
\hline Control & - & $6.68 \pm 0.30^{\mathbf{c}}$ & $1.18 \pm 0.06^{\mathbf{c}}$ & $14.06 \pm 0.73^{\mathrm{c}}$ \\
\hline \multirow{2}{*}{ Omega-3 } & $3^{\text {rd }}$ & $6.82 \pm 0.31^{\mathrm{c}}$ & $1.04 \pm 0.08$ & $14.88 \pm 0.65^{\mathrm{c}}$ \\
\hline & $8^{\text {th }}$ & $7.00 \pm 0.29$ & $1.28 \pm 0.03$ & $14.34 \pm 0.52^{\mathrm{c}}$ \\
\hline \multirow{2}{*}{ Irradiation } & $3^{\text {rd }}$ & $8.40 \pm 0.73^{\text {abd }}$ & $1.03 \pm 0.06$ & $11.18 \pm 0.71^{\mathbf{a b}}$ \\
\hline & $8^{\text {th }}$ & $7.98 \pm 0.32^{\mathrm{a}}$ & $1.41 \pm 0.09^{\mathrm{a}}$ & $18.12 \pm 1.20^{\text {abd }}$ \\
\hline \multirow{2}{*}{$\begin{array}{c}\text { Omega-3+ } \\
\text { Irradiation }\end{array}$} & $3^{\text {rd }}$ & $6.70 \pm 0.27^{\mathrm{c}}$ & $1.08 \pm 0.07$ & $13.08 \pm 0.80$ \\
\hline & $8^{\text {th }}$ & $7.44 \pm 0.40$ & $1.25 \pm 0.05$ & $14.84 \pm 0.71^{\mathrm{c}}$ \\
\hline
\end{tabular}

Legends as Table 1. 
Significant increase $(P<0.05)$ in uric acid level was recorded 3 and 8 days post irradiation while urea and creatinine levels showed an increase on the $8^{\text {th }}$ day post irradiation. Supplementation with omega- 3 ameliorates these increases (Table 5).

\section{Discussion}

The present study showed that exposing rats to whole body gamma irradiation (4Gy) induced oxidative stress expressed by elevation of serum MDA contents which is a one of the lipid peroxidation by-products concomitant with significant reduction in blood GSH content, SOD and GPX enzyme activities. These results are in concert with many previous studies which showed that total body irradiation induces lipid peroxidation in serum and different tissues and changes antioxidant enzyme activities (Adaramoye et al, $2011 \& 2012$ ). The ionizing radiation induced lipid peroxidation through the generation of ROS which attack the polyunsaturated fatty acids constituent of the cell membrane and other cell components (Zahran et al., 2006).

It is well documented that unchecked peroxidation decomposition of membrane lipids has severe consequences for the cell and the organism (Maurya, et al., 2006). Polyunsaturated fatty acids are considered essential for the structure of cell membrane, since their central role is to maintain its structure, fluidity and function (Kotzampassi et al., 2009). Attia and Nasr, (2009) recorded that an increase in saturated fatty acids or a reduction in polyunsaturated fatty acids in lipid membranes decreases the susceptibility of membranes to oxidant attack.

The omega-3 PUFAs are able to control, at least to some degree, the adverse effects of irradiation related to the inflammatory process produced where they are incorporated in the cellular membrane and modulate antiinflammatory cytokines production (Kotzampassi et al., 2009), enhance resistance to free radical attack and reduce lipid peroxidation (Erdogan et al., 2004). The results of this study suggest that pre-treatment with omega-3 before irradiation exerts an antioxidant effect by restoring the level of MDA and GSH and antioxidant enzyme activities within the normal levels. Such results corroborate the findings of Saito and Kubo (2003).

Egypt. J. Rad. Sci. Applic., Vol. 26, No. 1-2 (2013) 
Previous studies of (Sekine et al., 2006) demonstrated that tissue levels of ascorbic acid and/or glutathione increased in rats fed DHA. It was assumed that this increase would augment antioxidant potency in tissues and thus decrease lipid peroxidation. Furthermore, GSH is a necessary substrate for the antioxidant enzymes, GPX and GST. Ascorbic acid and GSH potentiate reductive recycling of vitamin $\mathrm{E}$, which augments its antioxidant activity (Scarpa et al., 1984). In fact, omega-3 or fish oil enhance antioxidant activity in different tissues; liver (Garrel et al., 2012), heart (Hunkar et al., 2002) and kidney (Bhattecharya et al, 2007), suggesting that their effects are not tissuespecific and may be related to increasing mRNA expression of SOD (Kesavalu et al., 2007) and GPX (Venkatraman, 1994) enzymes.

In this study, gamma irradiation induced a significant increase of total cholesterol and triglyceride levels, which runs in full agreement with the results of Ashry et al. (2009 \& 2010). They attributed this increase to the suppression of lipoprotein lipase activity that reduces the uptake of lipids by adipose cells in addition to decreases fatty acid oxidation and increased rate of cholesterol biosynthesis in the liver and other tissues. This study, revealed that omega-3 supplementation before irradiation has a modulatory effect on lipid profile disturbance induced by gamma -irradiation. So, it could be suggested that omega-3 exert a fat-lowering effect by regulating lipid metabolism through inhibiting lipogenesis (Tai and Ding, 2010) through decreasing the expression of lipogenic genes (Nakatani et al., 2003 and Xu et al., 1999), enhancing lipolysis through increasing the expression of hormone sensitive lipase and decreasing the expression of perilipin (Luo et al., 1998 and Wang, et al., 2009) and enhancing fatty acid oxidation which is mediated by increasing the oxidation-related enzyme activities (Guo et al., 2005 and Ide et al., 2000 ). In addition, omega-3PUFAs suppress pre-adipocyte differentiation and high concentration of EPA and DHA induces apoptosis of adipocytes and subsequently reduces adipogenesis (Perez-Matute et al., 2007 and Kim et al., 2006). This apoptic effect could results in decreased adipose accumulation (Tai and Ding, 2010).

It is well known that ALP and ALT are found predominantly in the liver. Injury or diseases affecting the liver causes a release of these enzymes into the 
blood stream. Radiation exposure caused damage to the cell membrane that augmented the ALP activity. The increase in ALT activity in serum reflects an increase plasma membrane permeability, which may be associated with cell death (Gharib, 2007).The fact that omega-3 PUFA could ameliorate gamma radiation -induced increase in serum ALT, AST and ALP enzyme activities point to their possible protective effect of the liver, probably mediated through reducing the levels of lipid peroxidation and improving antioxidant defence system observed in this work.

CPK, LDH and AST are important enzymes used to confirm a myocardial infarction or heart injury. The elevation in these enzyme activities after whole body gamma irradiation recorded in this study is in agreement with the previous findings of Fahim (2008) who attributed this increase to the alterations in dynamic permeability of membranes induced by ionizing radiation, allowing leaking of biological active materials out of the injured cells. The amount of these markers in plasma is directly proportional to the number of necrotic cells present in cardiac tissue (Farvin et al., 2004). Omega-3 pre-treatment reduced the increase of these diagnostic marker enzymes. The protective activity of omega-3 against gamma radiation induced stress injury is due to its ability to inhibit lipid accumulation by its hypolipidaemic property (Anandan et al., 2007) and to prevent myocardial necrosis and restore the normalcy of the structural and functional integrity of the myocardium (Gopal et al., 2011). The observed increase in urea, creatinine and uric acid levels after irradiation indicates kidney injury. This injury was ameliorated by supplementation of omega-3 before irradiation as recorded in these results. Brown et al. (1998) recorded that dietary supplementation with omega-3 was reno-protective, preventing deterioration of renal function and preserving renal structure. It also decreases blood pressure, a known accelerant of kidney disease propagation (Fassett et al., 2010). According to the above results it could be concluded that oral supplementation of omega-3 before irradiation enhances antioxidant activities, decrease lipid peroxidation and regulate lipid metabolism. So, it ameliorates liver, heart and kidney dysfunctions induced by ionizing radiation.

\section{References}

Adaramoye, O. A., Adedara, I. A. and Farombi, E. O. (2012) Possible ameliorative effects of kolaviron against reproductive toxicity in sub-lethally whole body gamma-irradiated rats. Exp. Toxicol. Pathol., 64, 379.

Egypt. J. Rad. Sci. Applic., Vol. 26, No. 1-2 (2013) 
Adaramoye, O. A., Okiti, O. and Farombi, E. O. (2011) Dried fruit extract from Xylopiaaethiopica (Annonaceae) protects Wistar albino rats from adverse effects of whole body radiation. Exp. Toxicol. Pathol., 63, 635.

Agrawal, A. and Kale, R. K. (2001) Radiation induced peroxidative damage: mechanism and significance. Indian J. Exp. Biol., 39, 291.

Anandan, R., Mathew, S., Sankar, T. V. and Viswanathan Nair, P. G. (2007) Protective effect of n-3 polyunsaturated fatty acids concentrate on isoproterenol-induced myocardial infarction in rats. Prostag. Leukot. Essent. Fatty Acid, 76, 153.

Ashry, O. M., Hussein, E. M. and Salama, S. F. (2009) Boosting of antioxidants defense by interferon-alfa in irradiated bone marrow transplanted rats. Egypt. J. Rad. Sci. Applic., 22, 19.

Ashry, O. M., Kafafy, Y. A. and El Tawil, G. R. (2010) Influence of hesperidin on lipid metabolism, oxidative stress and related trace elements in $\gamma$-Irradiated rats. Egypt. J. Rad. Sci. Applic., 23, 15.

Attia, A.. and Nasr, H. (2009) Evaluation of protective effect of Omega-3 fatty acids and selenium on paraquate intoxicated rats. Slovak J. Anim. Sci., 42, 180.

Barham, D. and Trinder, P. (1972) An improved colour reagent for the determination of blood glucose by the oxidase system. Analyst, 97, 142 .

Belfield, A. and Goldberg, D. M. (1971) Colorimetric determination of alkaline phosphatase activity. Enzyme, 12, 561.

Beutler, E., Duran, O. and Kelly, B. (1963) Improved method for the determination of blood glutathione. J. Lab. Clin. Med., 61, 852.

Bhattacharya, A., Sun, D., Rahman , M. and Fernandes, G. (2007) Different ratios of eicosapentaenoic and docosahexaenoic omega- 3 fatty acids in commercial fish oils differentially alter pro-inflammatory cytokines in peritoneal macrophages from C57BL/6 female mice. J. Nutr. Biochem.,18, 23.

Brown, S. A., Brown, C. A., Crowell, W. A., Barsanti, J. A., Allen, T., Cowell, C. and Finco, D. R. (1998) Beneficial effects of chronic administration of dietary polyunsaturated fatty acids in dogs with renal insufficiency. J. lab. Clin. Med., 131, 447.

Erdogan, H., Fadillioglu, E., Ozgocmen , S., Sogut , S., Ozyurt, B., Akyol, O. and Ardicoglu, O. (2004) Effect of fish oil supplementation on plasma oxidant/ antioxidant status in rats. Prostag. Leukot Essent Fatty Acids, 71, 149.

Fahim, TH. (2008) Possible Radio-Protective Efficiency of Bee-pollen against Radiation Induced Cardiotoxicity in Male Rats. Egypt. J. Rad. Sci. Applic., 21, 527.

Farvin, K. H. S., Anandan, R., Kumar, S. H. S., Shiny, K. S., Sankar, T. V. and Thankappan, T. K. (2004) Effect of squalene on tissue defence system in isoproterenol-induced myocardial infarction in rats. Pharmacol. Res., 50, 231.

Egypt. J. Rad. Sci. Applic., Vol. 26, No.1-2 (2013) 
Fassett, R. G., Gobe, G. C., Peake, J. M. and Coombes, J. S. (2010) Omega-3 Polyunsaturated fatty acids in the treatment of kidney disease. Am. J. kid. dis., 56, 728.

Fossati, P. and Prencipe, L. (1982) Serum triglycerides determined colourimetrically with an enzyme that produces hydrogen peroxide. Clin. Chem., 28, 2077.

Garrel, C., Alessandri, J. M., Guesnet, P. and Al-Gubory, K. H. (2012) Omega-3 fatty acids enhance mitochondrial superoxide dismutase activity in rat organs during post-natal development. Int. J. Biochem. Cell Biol., 44, 123.

Gharib, O. A. (2007) Does kombucha tea reduce the damage-induced by radiation exposure? Egypt. J. Rad. Sci. Applic., 20, 141.

Gopal, M. J., Mohan, M., Meganathan, P., Sasikala, N. Gowdhaman, K., Balamurugan, P., Nirmala and Santhakumari, S. A. (2011) Effect of dietary fish oil (omega-3-fatty acid) against oxidative stress in isoproterenol induced myocardial injury in Albino wistar rats. Global. J. Pharmacol., 5, 04.

Guo, W., Xie, W., Lei, T. and Hamilton, J. A. (2005) Eicosapentaenoic acid, but not oleic acid stimulates beta-oxidation in adipocytes. Lipids, 40, 815.

Henderson, A. R and Moss, D. W. (2001) Enzymes.Tietz Fundamentals of Clinical Chemistry, $5^{\text {th }}$ Ed., Burtis, C.A. and Ashwood, E.R. (eds.), Philadelphia, USA, p. 352.

Henry, R. J. (1974) Creatinine measurements with colorimetric method. Clin. Chem. principles and techniques. New York. Happer \& Row Publishers, p. 525.

Hunkar, T., Aktan, F., Ceylan, A. C. and Karasu, I. (2002) Effects of cod liver oil on tissue antioxidant pathways in normal and streptozotocin-diabetic rats. Cell Biochem. Funct., 20, 297.

Ibrahim, M. F.,Yacoub. S. F. and Abdel aziz, N. (2011) The similitude of some negative outcomes of Omega-3 to those of gamma radiation in pregnant albino rats and their fetuses. J. Rad. Res. Appl. Sci., 4, 577.

Ide, T., Kobayashi, H., Ashakumary, L., Rouyer, I. A., Takahashi,Y., Aoyama,T., Hashimoto, T. and Mizugaki, M. (2000) Comparative effects of perilla and fish oils on the activity and gene expression of fatty acid oxidation enzymes in rat liver. Biochim. Biophys. Acta, 1485, 23.

Kesavalu, L., Bakthavatchalu, V., Rahman, M.M., Su, J., Raghu, B., Dawson, D., Fernandes, G. and Ebersole, J. L. (2007) Omega-3 fatty acid regulates inflammatory cytokine/mediator messenger RNA expression in Porphyromonasgingivalis-induced experimental periodontal disease. Oral Microbiol. Immunol., 22, 232.

Kim, H. K., Della-Fera M., Lin J and Baile, C. A. (2006) Docosahexaenoic acid inhibits adipocyte differentiation and induces apoptosis in 3T3-L1 preadipocytes. J. Nutr., 136, 2965.

Egypt. J. Rad. Sci. Applic., Vol. 26, No. 1-2 (2013) 
kotzampassi, K., Tzitzikas, Y., Papavramidis, T. S., Kolettas, A., Vrettou, E., Spiliadi, C. H., Paramythiotis, D., Metaxas, G. and Eleftheriadis, E. (2009) n-3 fatty acids ameliorate radiation-induced liver injury in the rat. Annals Gstroenterol., 22, 106.

Lavie, C. J., Milani, R. V., Mehra, M. R. and Ventura, H. O. (2009) Omega-3 Polyunsaturated Fatty Acids and Cardiovascular Diseases. J. Am. Coll. Cardiol., 54, 585.

Luo, J., Rizkalla, S. W., Vidal, H., Oppert, J. M. and Colas, C. (1998) Moderate intake of n-3 fatty acids for 2 months has no detrimental effect on glucose metabolism and could ameliorate the lipid profile in type 2 diabetic men. Results of a controlled study. Diabetes Care, 21, 717.

Maurya, D. K., Devasagayam, T. P. A. and Nair, C. K. K. (2006) Some novel approaches for radioprotection and the beneficial effect of normal product. Indian J. Exp. Biol., 4, 93.

Miller, E. R., Juraschek, S. P., Appel, L. J., Madala, M., Anderson, C., Bleys, J. and Guallar, E. (2009) The effect of n-3 long-chain polyunsaturated fatty acid supplementation on urine protein excretion and kidney function: metaanalysis of clinical trials1-3. Am. J. Clin. Nutr., 89, 1937.

Misra, H. and Fridovich, I. (1972) The role of superoxide anion in the autoxidation of epinephrine and a simple assay for superoxide dismutase. J. Biol. Chem., 247, 3170 .

Nakatani, T., Kim, H. J., Kaburagi, Y., Yasuda, K. and Ezaki, O. A. (2003) Low fish oil inhibits SREBP-1proteolytic cascade while a high-fish-oil feeding decreases SREBP-1 mRNA in mice liver: relationship to anti-obesity. $J$. Lipid Res., 44, 369.

Paglia, D. E. and Valentine, W.N., (1967) Studies on the quantitative and qualitative characterization of erythrocyte glutathione peroxidase. J. Lab. Chem. Med., 70, 158.

Patton, C. and Crouch, S. (1977) Spectrophotometric and kinetics investigation of the Berthelot reaction for the determination of ammonia. Anal. Chem., 49, 464.

Perez-Matute, P., Perez-Echarri, N., Martinez, J. A., Marti, A. and MorenoAliaga, M. J. (2007) Eicosapentaenoic acid actions on adiposity and insulin resistance in control and high-fat-fed rats: role of apoptosis, adiponectin and tumour necrosis factoralpha.Br. J. Nutr., 97, 389.

Rec, (1977) German Clinical Chemistry Society. Kinetic determination of creatine phosphokinase activity. J. Clin. Biochem., 15, 255.

Reitman, S. and Frankel, S. (1957) A colorimetric method for the determination of serum glutamic oxaloactic and glutamic pyruvic transaminases. Am. J. Clin. Pathol., 28, 56. 
Richmond, W. (1973) Preparation and properties of a cholesterol oxidase from Nocardia sp. and its application to the enzymatic assay of total cholesterol in serum.Clin.Chim.,19 , 1350.

Rupp, H., Rupp,T. P., Alter, P. and Maisch, B. (2012) Mechanisms involved in the differential reduction of omega-3 and omega-6 highly unsaturated fatty acids by structural heart disease resulting in "HUFA deficiency". Can. J. Physiol. Pharmacol., 90, 55.

Saito, M. and Kubo, K. (2003) Relationship between tissue lipid peroxidation and peroxidizability index after a-linolenic, eicosapentaenoic, or docosahexaenoic acid intake in rats. Br J Nutr., 89, 19.

Sandeep, D. and Nair C. K. (2012) Protection from lethal and sub-lethal whole body exposures of mice to $\gamma$-radiation by Acoruscalamus L.: studies on tissue antioxidant status and cellular DNA damage. Exp Toxicol pathol. 64, 57.

Scarpa, M., Rigo, A., Maiorino, M., Ursini, F. And Gregolin, C. (1984) Formation of alpha-tocopherol radical and recycling of alpha-tocopherol by ascorbate during peroxidation of phosphatidylcholine liposomes. An electron paramagnetic resonance study. Biochim. Biophys. Acta, 801, 215.

Sekine, S., Kubo, K., Tadokoro, T. and Saito, M. (2006) Dietary docosahexaenoic acid-induced generation of liver lipid peroxides is not suppressed further by elevated levels of glutathione in ODS rats. Nutrition, 22, 385.

Sener, G., Kabasakal, L., Atasoy, B. M., Erzik, C., Velioğlu-Oğünç, A., Cetinel, S., Contuk, G., Gedik, N. and Yeğen, B. C. (2006) Propylthiouracilinduced hypothyroidism protects ionizing radiation-induced multiple organ damage in rats. J. Endocrinol., 189, 257.

Tai, C. C. and Ding, S. T. (2010) N-3 polyunsaturated fatty acids regulate lipid metabolism through several inflammation mediators: mechanisms and implications for obesity prevention. J. Nutr. Biochem., 21, 357.

Venkatraman, J. T., Chandrasekar, B., Kim, J. D. and Fernandes, G. (1994) Effects of n-3 and n-6 fatty acids on the activities and expression of hepatic antioxidant enzymes in autoimmune-prone NZBNZW F1 mice. Lipids, 29, 561.

Wang, Y. C., Kuo, W. H., Chen, C. Y., Lin, H. Y., Wu, H. T. and Liu, B. H. (2009) Docosahexaenoic acid regulates serum amyloid A protein to promote lipolysis through down regulation of perilipin. J. Nutr. Biochem., 58, 909.

Xu, J., Nakamura, M. T., Cho, H. P. and Clarke, S. D. (1999) Sterol regulatory element binding protein-1 expression is suppressed by dietary polyunsaturated fatty acids. A mechanism for the coordinate suppression of lipogenic genes by polyunsaturated fats. J. Biol. Chem., 274, 23577.

Yoshioka, T., Kawada, K., Shimada, T. and Mori, M. (1979) Lipid peroxidation in maternal and cord blood end protective mechanism against activated-oxygen toxicity in the blood. Am. J. Obstet. Gynecol., 35, 375.

Egypt. J. Rad. Sci. Applic., Vol. 26, No. 1-2 (2013) 
Zahran, A. M., Azab, KH. SH. and Abbady, M. (2006) Modulatory role of allopurinol on xanthine oxidoreductase system and antioxidant status in irradiated rats. Egypt J .Rad. Sci. Applic., 19, 373.

Zhao, W., Diz, D. I. and Robbins, M. E. (2007) Oxidative damage pathways in relation to normal tissue injury. Br. J. Radiol., 80, S23.

(Received: 10/03/2013;

accepted: 21/04/2013) 


$$
\begin{aligned}
& \text { احمـاض أوميجـا ب الدهنيه غير المشبعه تخفف من الاجهاد التأكسدى }
\end{aligned}
$$

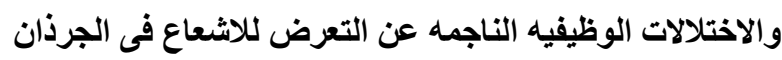

$$
\begin{aligned}
& \text { ناهد عبد العزيز ، و سوزى فوزى يعقوب }
\end{aligned}
$$

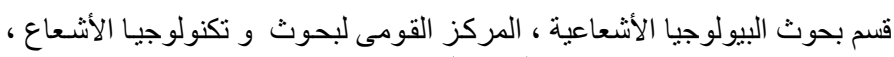

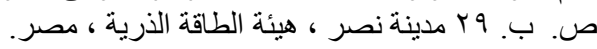

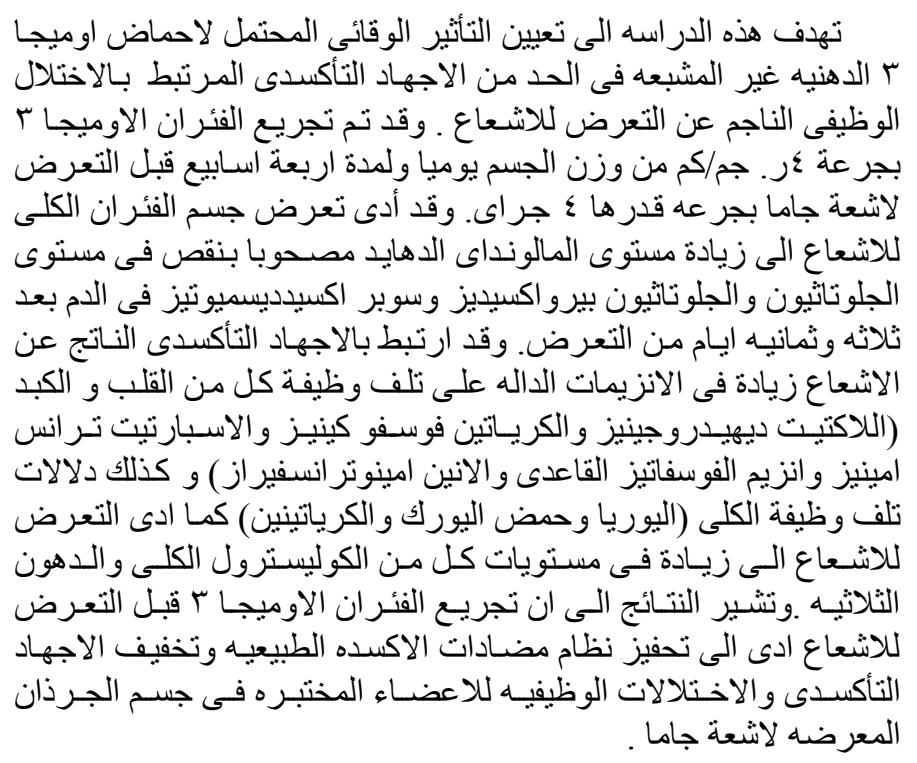

Egypt. J. Rad. Sci. Applic., Vol. 26, No. 1-2 (2013) 